
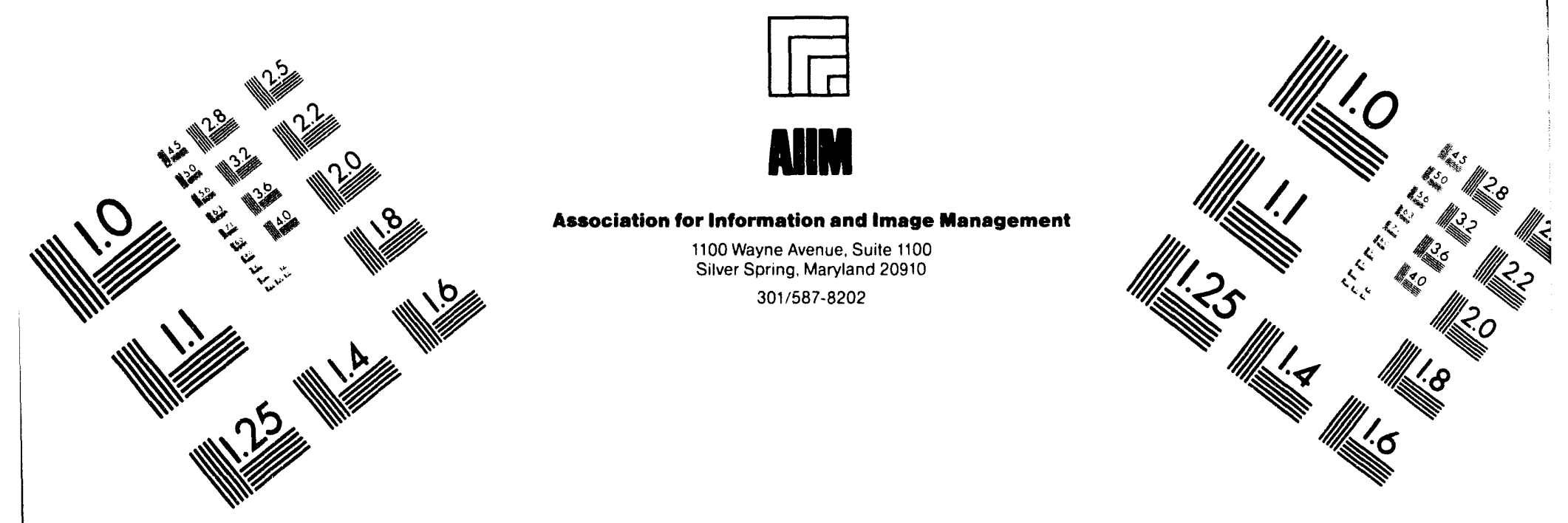

\title{
Centimeter
}

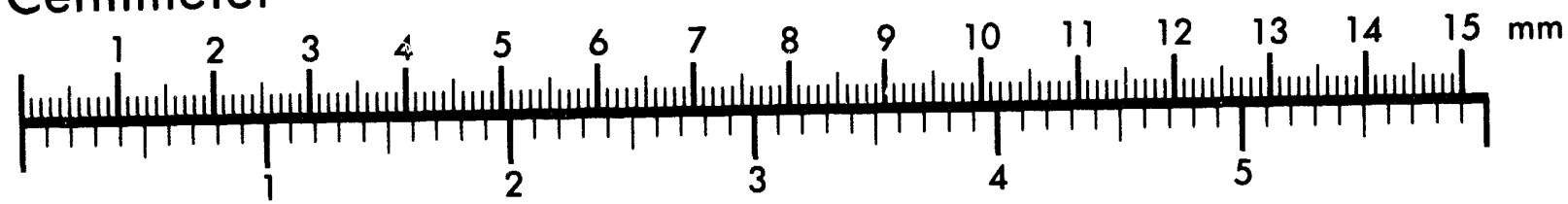
Inches
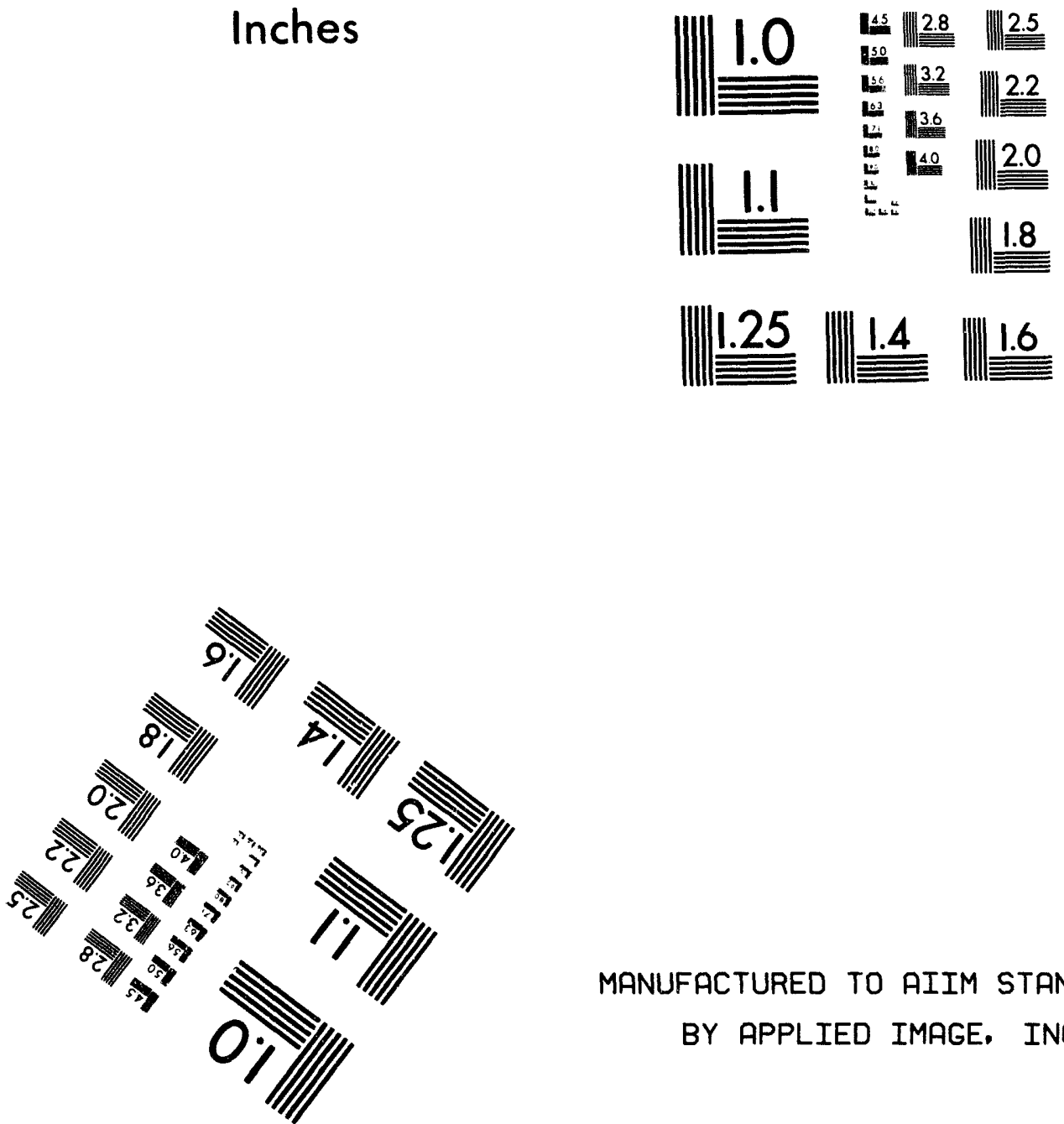

MANUFACTURED TO AIIM STANDARDS

BY APPLIED IMAGE, INC.

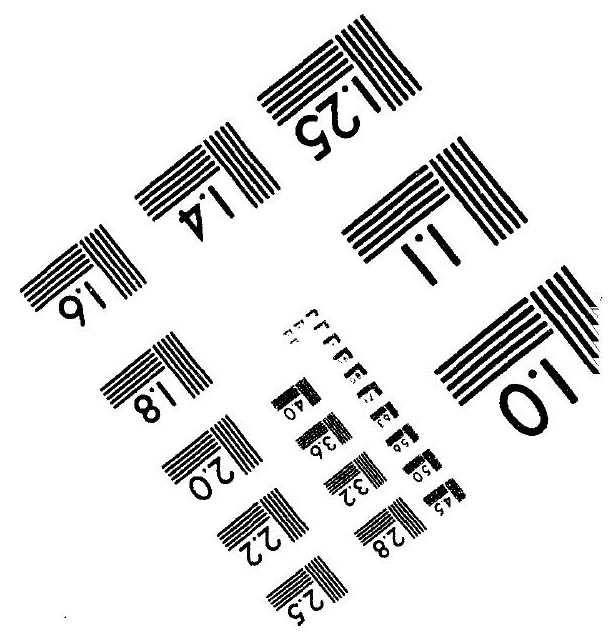



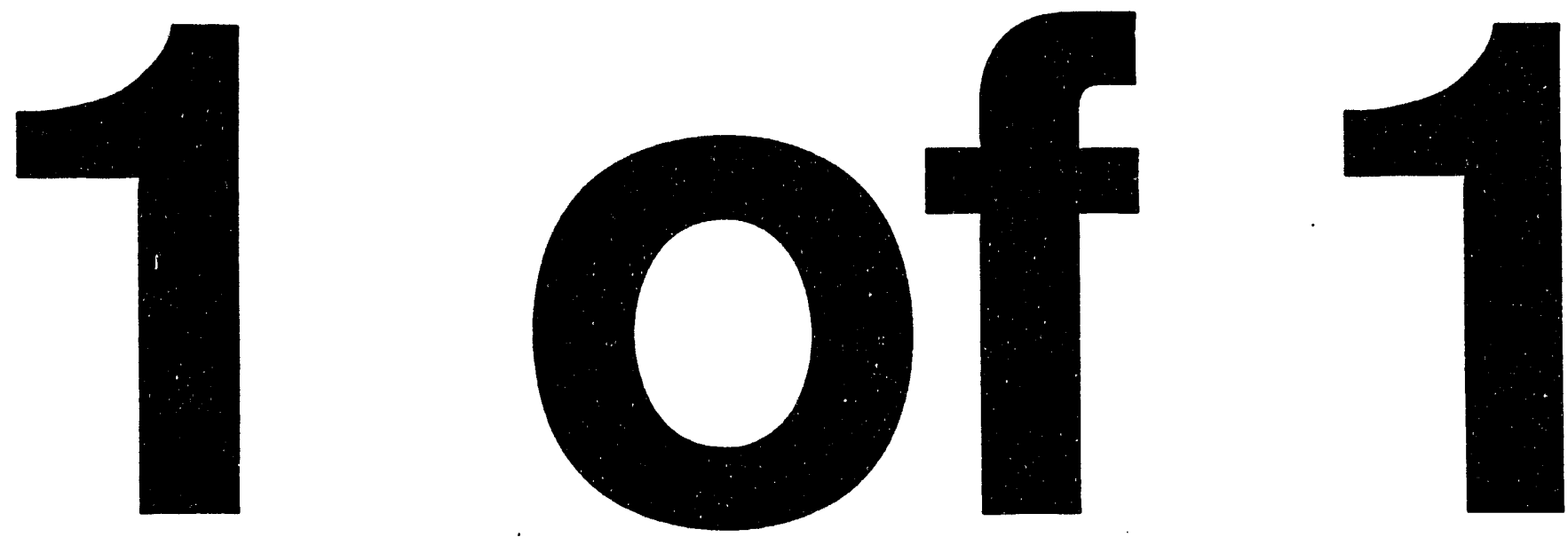


\title{
Conf- $940706--1$
}

\section{Application of Diode Lasers to the Isotopically Selective Determination of Uranium in Oxides by Optogalvanic Spectroscopy}

\author{
J. P. Young, C. M. Barshick, R. W. Shaw \\ and J. M. Ramsey \\ Chemical \& Analytical Sciences Division, Oak Ridge National Laboratory, \\ P. O. Box 2008, Oak Ridge, TN 37831-6142
}

\begin{abstract}
We have observed isotopically selective diode laser-excited optogalvanic effects in uranium at 778.42 and $776.19 \mathrm{~nm}$. The samples were natural abundance uranium oxide, as well as depleted $(0.3 \%$ 235U), natural $(0.7 \%$ $235 \mathrm{U})$ and enriched $(9.75 \% 235 \mathrm{U})$ uranium metal or powders. The measurements were carried out in a demountable-cathode glow discharge cell. Preliminary evaluations of precision for uranium isotopic ratios measured using this technique suggest that it should have broad analytical applications for uranium and other amenable actinides or lanthanides.
\end{abstract}

\section{INTRODUCTION}

Previously, tunable semiconductor diode lasers were used to promote transitions in gaseous lanthanum atoms with isotopic selectivity (1). As a basis for a useful analytical determination, we used a diode laser to achieve isotopically selective excitation of gaseous uranium atoms generated from samples of uranium or uranium oxide by sputtering in a demountable hollow-cathode glow discharge (GD) cell. The excitation process was monitored by optogalvanic spectroscopy (OGS). Uranium has been studied by OGS in commercial hollow-cathode lamps at $778.42 \mathrm{~nm}(2,3)$. Isotope detection was achieved in one study using a single frequency $\mathrm{CW}$ dye laser (2). Dinde lasers were used to observe $2.38 \mathrm{U}$ in another study (3), but no isotopic selectivity was noted. Our work was carried out to evaluate the possibility of developing fieldable instrumentation for the estimation of isotope ratios of uranium containing samples. Instrumentation based on diode laser excitation of a sputtered sample in a GD cell followed by OGS detection should have broad application.

\section{EXPERIMENTAL}

The details of the experimental work for these studies are described elsewhere (4) but are summarized here. The demountable-cathode GD cell is shown in Figure 1. It consists of standard vacuum crosses fitted with two windows. The cathode assembly is removable through the top of the cell. The sample cathode was fabricated by pressing uranium powder or a 50-50\% mixture of uranium oxide and silver powder into a hollow cylinder that was approximately $5 \mathrm{~mm}$ diameter, 2.5 $\mathrm{mm}$ long with a $2.4 \mathrm{~mm}$ hole in the center. This sample fits into the ring at the base of the cathode. A special die was made for sample preparation; a pressure of $3 \times 10^{7}$

The subnitted menuacript hes been outhored by a contrictor of the U.S. Governmem under contract No. DEACO5-84OR2 1400. Accordingty. the U.S. Governmmi reteine a nonoxctuaive. rovelty-tres licenas to publish or reproduce the publinted form of this contribution, or wow others to do so, for U.S. Government purpowe."

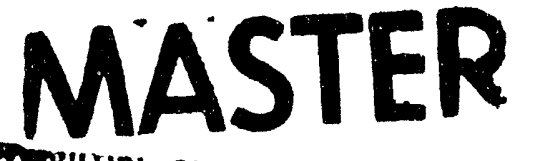

UTONmBIIIION OF THIS UDCUMENT IS UNLIMITEI 


\section{DISCLAIMER}

This report was prepared as an account of work sponsored by an agency of the United States Government. Neither the United States Government nur any agency thereof, nor any of their employees, makes any warranty, express or implied, or assumes any legal liability or responsibility for the accuracy, completeness or usefulness of any information, apparatus, product, or process disclosed, or represents that its use would not infringe privately owned rights. Reference herein to any specific commercial product, process, or service by trade name, trademark, manufacturer, or otherwise does not necessarily constitute or imply its endorsement, recommendation, or favoring by the United States Government or any agency thereof. The views and opinions of authors expressed herein do not necessarily state or reflect those of the United States Government or any agency thereof. 
$\mathrm{Pa}$ for five minutes was necessary to form the cathodes. Several uranium samples were used in these studies, natural abundance uranium and $\mathrm{U}_{3} \mathrm{O}_{8}(0.7 \% 23 \mathrm{SU})$, depleted uran um powder ( $0.3 \% 235 \mathrm{U})$, and enriched uranium ( $10 \% 23 \mathrm{SU})$. After loading the cathode into the cell, a discharge was maintained in argon support gas ( 500 to $900 \mathrm{~Pa}$ ); the current was held constant in the range of 20 to $50 \mathrm{~mA}$ at an applied discharge voltage of 250 to $500 \mathrm{~V}$. Sample manipulation was accomplished by movement of the cathode probe assembly from outside the cell. The cell body served as the counter electrode of the discharge.

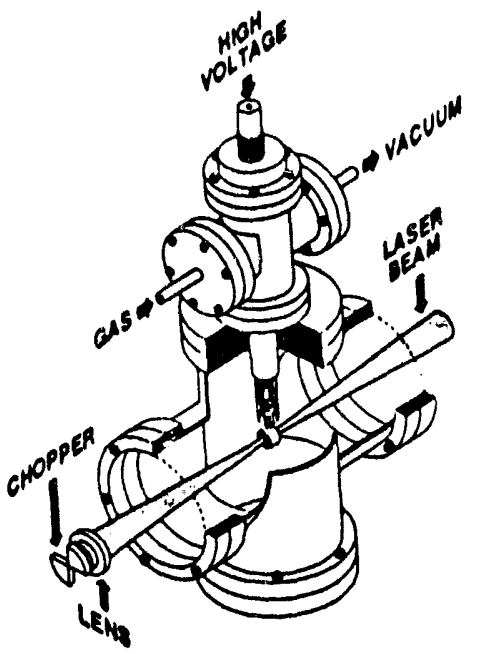

The OGS studies were carried out with either of two CW lasers. One was an argonion laser-pumped titanium:sapphire (Ti:S) tunable ring laser (Innova-100 argon ion laser and model 899-29 Ti:S ring laser. Coherent Laser Group, Santa Clara, CA). The output power of this system was $1 \mathrm{~W}$, but was generally attenuated. The other laser was an AlGaAs semiconductor diode laser (model ML-64110N, Mitsubishi Electric Corp., Tokyo) with a nominal room temperature output of $30 \mathrm{~mW}$ at $777 \mathrm{~nm}$. The diode laser was used with commercial control electronics (model LDM-4412 laser

Figure 1. Demountable hollow cathode glow discharge cell.

r.ount, LBT-5910 thermoelectric temperature controller, and LDX-3620 ultra-low noise current source, ILX Lightwave Corporation, Bozeman, MT). The manufacturer's specification states that the temperature is controlled to $\pm 0.005^{\circ} \mathrm{C}$ and the current supply noise is $2 \mu \mathrm{A}$ or less. Either laser beam was directed through the sample as a focused heam ( $50 \mu$ dia.) or, more recently, as a pencil of light of $1 \mathrm{~mm}$ diameter. The diode laser power at the experimental wavelengths of 778.42 or $776.12 \mathrm{~nm}$ was 3 and $8 \mathrm{~mW}$, respectively, with focused power densities of 150 and $400 \mathrm{~W} / \mathrm{cm}^{2}$. As shown in Figure 1, either laser beam was chopped at $1000 \mathrm{~Hz}$ with a mechanical chopper (model SR540, Stanford Research Systems. Inc., Sunnyvale, CA).

For OGS measurement, the ac component of the cathode voltage was routed to a digital oscilloscope (model 2246A, Tektronix, Inc.. Beaverton, OR) and a lock-in amplifier (model SR510, 1s time constant, Stanford Research Systems, Inc., Sunnyvale, CA). The output of the lock-in was digitized by the Ti:S control computer or, in the case of the diode laser, a separate computer.

\section{RESULTS AND DISCUSSION}

We have observed and studied isotopically selective OGS at 778.42 and $776.19 \mathrm{~nm}$ with diode laser excitation.in samples of uranium in a demountable GD cell. The two excitation processes are described in Table 1 along with other information available for these transitions $(5,6)$. 
Table I. Uranium Transitions of Interest

\begin{tabular}{|cccc|}
\hline $\begin{array}{c}\text { Wavelength } \\
(\mathrm{nm})\end{array}$ & $\begin{array}{l}\text { Transition }(\mathrm{cm} \cdot 1) \\
\text { Term symbols }\end{array}$ & $\begin{array}{c}\text { Relative Emission } \\
\text { Intensity (5) }\end{array}$ & $\begin{array}{c}\text { Isolope Shift (6) } \\
(\mathrm{G}-\mathrm{z})\end{array}$ \\
\hline 778.42 & $\begin{array}{l}620 \rightarrow 13463 \\
5 \mathrm{~K}_{5} \cdot 5 K_{6}\end{array}$ & 425 & 3.0 \\
776.19 & $\begin{array}{l}7005 \rightarrow 19885 \\
3 \mathrm{~K}_{6} \cdot 5 \mathrm{M}_{7}\end{array}$ & 30 & -12.6 \\
\hline
\end{tabular}

In Figure 2, we show $O G$ spectra at 778.42 of uranium in a pellet of $\mathrm{U}_{3} \mathrm{O}_{8}$-silver. It is noteworthy that the GD process liberates free uranium atoms from an oxide sample. In the lower spectrum, the $238 \mathrm{U}$ is on scale. The upper spectral response was enhanced to show the $235 \mathrm{U}$ hyperfine structure adjacent to the $238 \mathrm{U}$ line. Although this wavelength is diode laser accessible, these spectra were obtained using the Ti:S ring laser. The observed $238 \mathrm{U}$ linewidth was $925 \mathrm{MHz}$ fwhm at the laser power density of $1 \times 10^{5} \mathrm{~W} / \mathrm{cm}^{2}$. This power density is much higher than that of diode lasers, but similar spectra were also observed at laser power densities on the order of $400 \mathrm{~W} / \mathrm{cm}^{2}$ by attenuating the Ti:S laser beam.

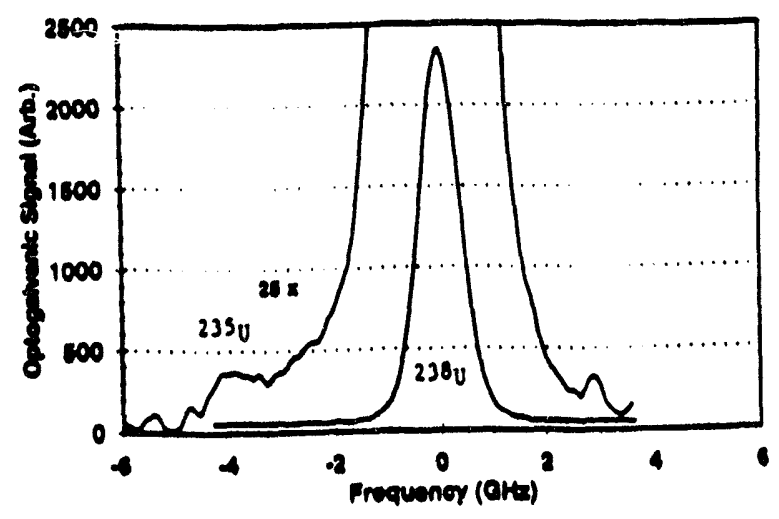

Figure 2. $O G$ spectrum of uranium in natural abundance $U_{3} \mathrm{O}_{8}$ sputtered in a glow discharge.

Note in the upper spectrum of Figure 2 that the hyperfine structure of $235 \mathrm{U}$ can be seen in the base of the 238U OGS line. The width of the hyperfine structure for $235 \mathrm{U}$ for this transition has not been published, but it can be seen that there is not complete resolution of the two isotopic features.

Examining the second entry in Table $I$, it is apparent that a much larger isotope shift is available if one can use the $776.19 \mathrm{~nm}$ transition as the basis of an OGS process. This excitation represents a transition from the highest-lying metastable state of uranium. The relative emission intensity is weak, but these intensities do not relate directly to OGS. In Figure 3 we compare the diode laser excited OGS spectra at 778.42 and $776.19 \mathrm{~nm}$ for an enriched metal uranium sample $(10 \% 235 \mathrm{U})$. The diode laser power densities at the sample were $150 \mathrm{~W} / \mathrm{cm}^{2}$ 
$(3 \mathrm{~mW})$ and $400 \mathrm{~W} / \mathrm{cm}^{2}(8 \mathrm{~mW})$, respectively. There is complete separation of the $235 \mathrm{U}$ hyperfine structure and the $238 \mathrm{U}$ line at $776.19 \mathrm{~nm}$ corresponding to the isotope shift (6) given in Table I. The relative intensities of the two OGS spectra cannot be assessed from the figure, but in other studies with the Ti:S laser at essentially constant power over these spectral ranges, the $776 \mathrm{~nm}$ OGS spectrum was only five times less intense than the $778 \mathrm{~nm}$ spectrum.

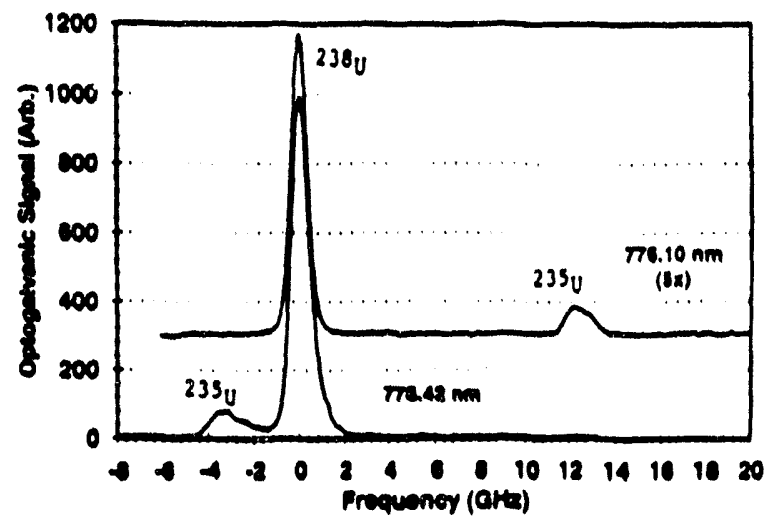

Figure 3. OG spectra of enriched $(9.75 \%$ 235U) uranium metal at 778.42 and $776.19 \mathrm{~nm}$.

Currently we are carrying nut a further evaluation of the $776.19 \mathrm{~nm}$ OGS transition. We examined depleted uranium and were able to quantify the minor 235U isotope at this wavelength. In preliminary measurements of uranium isotope ratios by OGS, we have obtained run-to-run and sample-to-sample precisions of better than $\pm 1 \%$ or $\pm 3 \%$ relative standard deviation, respectively, at either wavelength.

\section{ACKNOWLEDGEMENTS}

Research sponsored by U.S. Department of Energy, Office of Research and Development. Oak Ridge National Laboratory is managed by Martin Mariella Energy Systems, Inc., for DOE under contract DE-AC05-84OR21400.

\section{REFERENCES}

1. Shaw, R. W., Young, J. P., Smith, D. H., Bonanno, A. S., and Dale, J. M., Phys, Rev. $A, 41,2566.2573$ (1990).

2. Keller, R. A.; Engleman, R., Jr.; Zalewski, E. F., J. Opt. Sc:. Amer., 69, 738-740 (1979).

3. Liper, R. J., Lee, S. C., and Edelson, M. C., Appl. Spectrosc., 46, 1307-1309 (1992).

4. Barshick, C. M., Shaw, R. W., Young, J, P., and Ramsey, J. M., submilted for publication (1994).

5. Palmer, B. A., Keller, R. A., and Engleman, Jr., R., "An Allas of Uranium Emission Intensities in a Hollow Cathode Discharge", LA-8251-MS; July 1980.

6. Engleman, R., and Palmer, B. A., J. Opt. Soc. Ämer., 70, 308.317 (1980). 

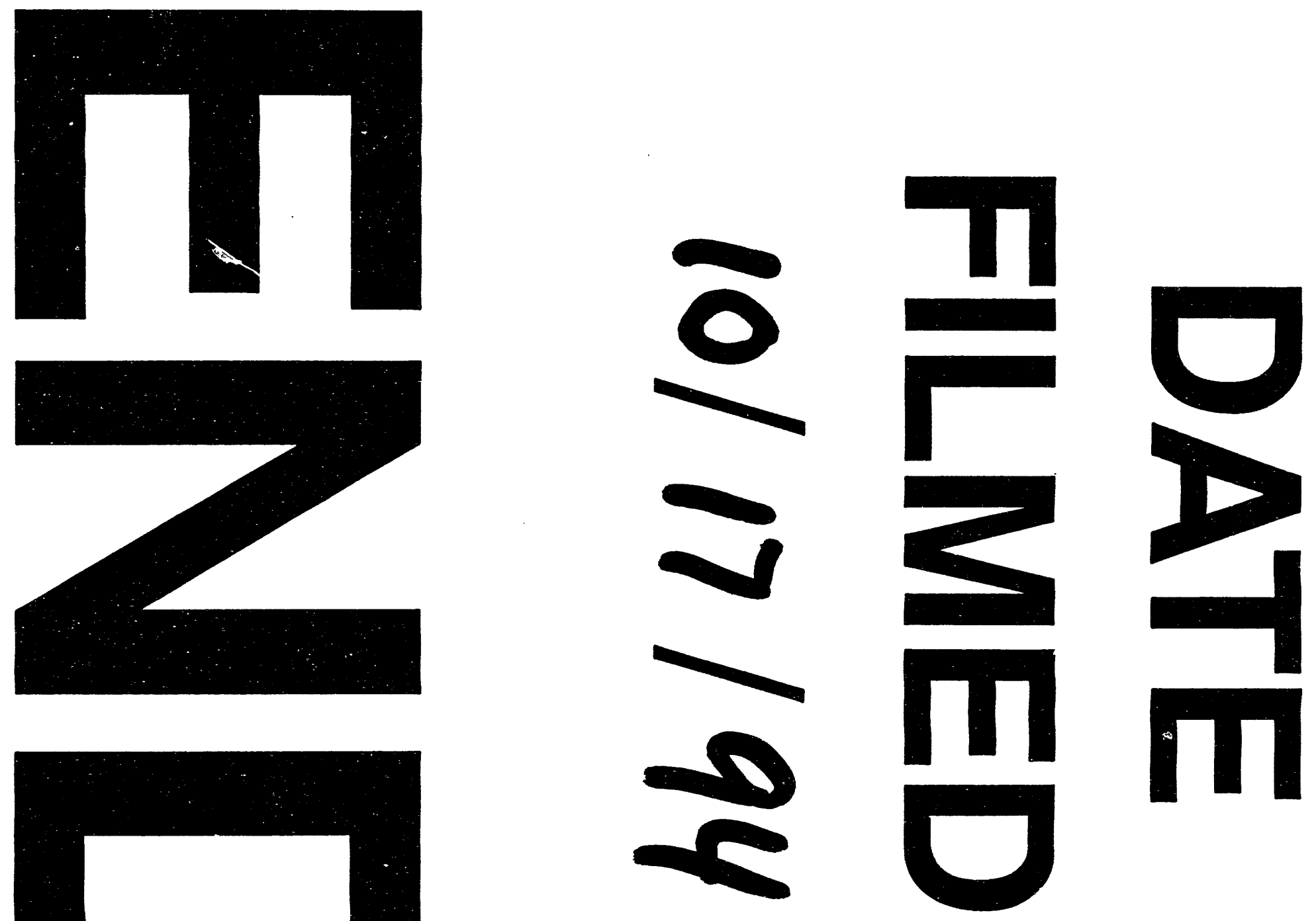
